\title{
DOI https://doi.org/10.30525/978-9934-26-041-4-69
}

\section{МОДЕЛЬ ПІДГОТОВКИ МАЙБУТНІХ ВЧИТЕЛІВ ПОЧАТКОВОЇ ОСВІТИ В ПЕДАГОГІЧНИХ КОЛЕДЖАХ ДО ІНТЕГРОВАНОГО НАВЧАННЯ УЧНІВ}

\author{
Драч I. I. \\ доктор педагогічних наук, дочент, \\ перший заступник директора \\ Інститут вищої освіти \\ Національної академії педагогічних наук України \\ м. Київ, Україна \\ Поберецька В. В. \\ аспірант \\ Інститут вищої освіти \\ Начіональної академії педагогічних наук України \\ м. Київ, Украӥна, \\ викладач філологічних дисциплін \\ КЗВО «Барський гуманітарно-педагогічний коледж \\ імені Михайла Грушевського» \\ м. Бар, Вінницька область, Україна
}

В педагогічній науці процес підготовки майбутніх вчителів початкової освіти до інтегрованого навчання учнів до теперішнього часу залишається недостатньо вивченим. Сучасні умови навчання не вирішують в належній мірі проблеми поетапного навчання майбутніх вчителів професійним діям, без чого неможливо сформувати творчо працюючого педагога, навчити його прийняття рішень, який передбачає оцінку умов; аналізу наявної інформації та ії відбору для трансляції та введення в систему комунікації 3 учнями і іншим професійним діям.

Система підготовки майбутніх вчителів початкової освіти в педагогічних коледжах сьогодні не передбачає підготовку до викладання на інтегративної основі. У зв'язку з цим підготовка студентів - майбутніх вчителів початкових освіти вимагає корекції. Так як якість підготовки фахівця залежить, по-перше: від поставлених цілей навчання, по-друге: від змісту навчання, по-третє: від принципів організації навчального процесу, необхідні зміни повинні торкнутися i цільових, і змістовних, і процесуальних компонентів навчання. 
Тому однією із задач дослідження визначено теоретичне обгрунтування й розробка моделі підготовки вчителів початкової освіти в педагогічних коледжах до інтегрованого навчання учнів.

3'ясовано, що особливості моделювання педагогічних процесів розглянуті у дослідженнях О. Дубасенюк [1, с. 16], Л. Капченка [2], О. Капінуса [3, с. 85] та ін. Ми погоджуємося авторами, що під час моделювання потрібно прагнути реалізувати певні функції, які властиві цьому процесові, а саме: ілюстративну; пояснювальну; критеріальну; прогностичну; перетворювальну.

Обгрунтована модель передбачає досягнення певного результату підвищення рівня готовності майбутніх вчителів початкової освіти до інтегрованого навчання учнів.

У моделі виокремлено такі основні блоки: методологічно-цільовий, змістово-процесуальний та результативний, які взаємопов'язані між собою та впливають один на одного.

До складу методологічно-цільового блоку віднесли соціальне замовлення на підготовку компетентних вчителів початкової освіти, мету, завдання, методологічні підходи та принципи, суб'єкти освітнього процесу (студенти, викладацький склад, вчителі початкової освіти) та етапи реалізації моделі.

Мета створення моделі - дослідження основних характеристик підготовки вчителів початкової освіти; прогнозування результатів професійного навчання студентів та їхньої готовності до інтегрованого навчання учнів.

Модель передбачає побудову процесу підготовки вчителів початкової освіти у педагогічних коледжах як системи, яка забезпечує трансформацію теоретичних знань в практичні вміння, дії. Вважаємо, що реалізація моделі сприятиме розв'язанню таких завдань: розвитку мотивації, педагогічного мислення студентів, їх здібностей; формування системи знань, педагогічних умінь та навичок для здійснення інтегрованого навчання в практичній роботі 3 учнями, освоєння методів і прийомів педагогічної діяльності.

Теоретичною та методологічною основою для розробки моделі підготовки вчителів початкової освіти в педагогічних коледжах до інтегрованого навчання учнів $\epsilon$ використання як загальних дидактичних підходів до цього процесу, так і специфічних, зумовлених особливостями педагогічних інтеграційних процесів: системного, аксіологічного, компетентнісного, інтеграційного, тому що вони найбільш відповідають цілям та завданням дослідження. 
Моделюючи процес підготовки студентів педагогічних коледжів майбутніх вчителів до інтегрованого навчання учнів, виділяємо наступні етапи: підготовчий; практичний; коригуючий.

Змістово-процесуальний блок моделі включає теоретичні основи дисциплін циклу загальної (гуманітарної та фундаментальної) та професійної (психолого-педагогічної та науково-предметної) підготовки.

Вагому роль у змістово-процесуальному блоці моделі підготовки студентів педагогічних коледжів - майбутніх вчителів початкової освіти до інтегрованого навчання учнів мають навчальні дисципліни психолого-педагогічного та методичного циклів, під час вивчення яких відбувається формування окремих елементів знань і умінь 3 педагогічної інтеграції.

У моделі підготовки вчителів початкової освіти в педагогічних коледжах до інтегрованого навчання учнів визначено та обгрунтовано комплекс педагогічних умов іiі реалізації: 1) формування позитивної мотивації майбутніх учителів початкової освіти до здійснення інтегрованого навчання учнів; 2) оновлення змісту, форм та методів фахової підготовки майбутніх учителів через включення компонентів, які відображають методологічні, теоретичні та методичні проблеми інтеграції в початковій освіті; 3) застосування в процесі професійної підготовки інтегративних методів і форм навчання на аудиторних заняттях, під час практик, в самостійній роботі студентів для набуття досвіду використання та удосконалення навичок здійснення інтегрованого навчання учнів.

Підготовка студентів до інтегрованого навчання учнів початкової школи здійснюється протягом усього періоду неперервної підготовки студентів у педагогічних коледжах та реалізується в різноманітних формах, які взаємопов'язані, доповнюють одна одну і створюють єдиний процес професійної підготовки майбутніх учителів початкової освіти. Серед форм підготовки майбутніх учителів початкової освіти до інтегрованого навчання учнів початкової школи визначаємо аудиторне навчання: лекції (проблемні, лекції-дискусії), лабораторні, практичні та семінарські заняття (робота в малих групах, тренінги вирішення педагогічних задач), та позааудиторне навчання (самостійна та індивідуальна робота, науково-дослідницька робота, педагогічна практика). Самостійна та індивідуальна робота студентів у процесі створення інтегрованих уроків спонукає до самостійності студентів, сприяє кращому засвоєнню навчального матеріалу. Ці форми взаємопов'язані, взаємодоповнювані та забезпечують єдиний процес підготовки майбутніх фахівців до інтегрованого навчання учнів. 
До основних методів підготовки майбутніх вчителів початкової освіти в педагогічних коледжах до інтегрованого навчання учнів відносимо традиційні та інноваційні методи: словесні, активні, дидактичні ігри, перегляд відеоуроків, спостереження та аналіз, метод проєктів, метод мозкового штурму, репродуктивні, проблемнопошукові, контролю і самоконтролю; case-stady, e-learning, перевернуте навчання, проблемні ситуації.

Результативний блок моделі охоплює критерії, рівні готовності вчителів початкової освіти до інтегрованого навчання учнів, як певний результат та реалізується на коригуючому етапі моделі. Цей етап передбачає рефлексію власної діяльності та формування рефлексивного компоненту готовності майбутніх учителів початкової освіти до інтегрованого навчання учнів.

Оцінювання результативності моделі здійснювалося шляхом аналізу динаміки рівнів сформованості компонентів готовності за визначеними критеріями за допомогою комплексу діагностичних методик.

Означена модель відображає загальні умови, які забезпечують підготовку студентів - майбутніх учителів початкової освіти до інтегрованого навчання учнів і потребує експериментальної перевірки.

\section{Лiтература:}

1. Професійна педагогічна освіта: інноваційні технології та методики : монографія / за ред. О. А. Дубасенюк. Житомир : Вид-во ЖДУ ім. І. Франка, 2009. 504 с.

2. Капченко Л. М. Моделювання організаційно-педагогічної діяльності в системі управління професійно-технічними навчальними закладами : автореф. ди с. ... канд. пед. наук : 13.00.07. Київ, 2002. 20 с.

3. Капінус О. С. Практичні підходи до побудови моделі формування соціальної відповідальності у майбутніх офіцерів на основі застосування засобів інтерактивних технологій. Науковий вісник Чернівецького університету: зб. наук. пр. Чернівці, 2014. Вип. 679: Педагогіка та психологія. С. 83-91. 